\title{
Corn Ethanol: The Surprisingly Effective Route for Natural Gas Consumption in the Transportation Sector
}

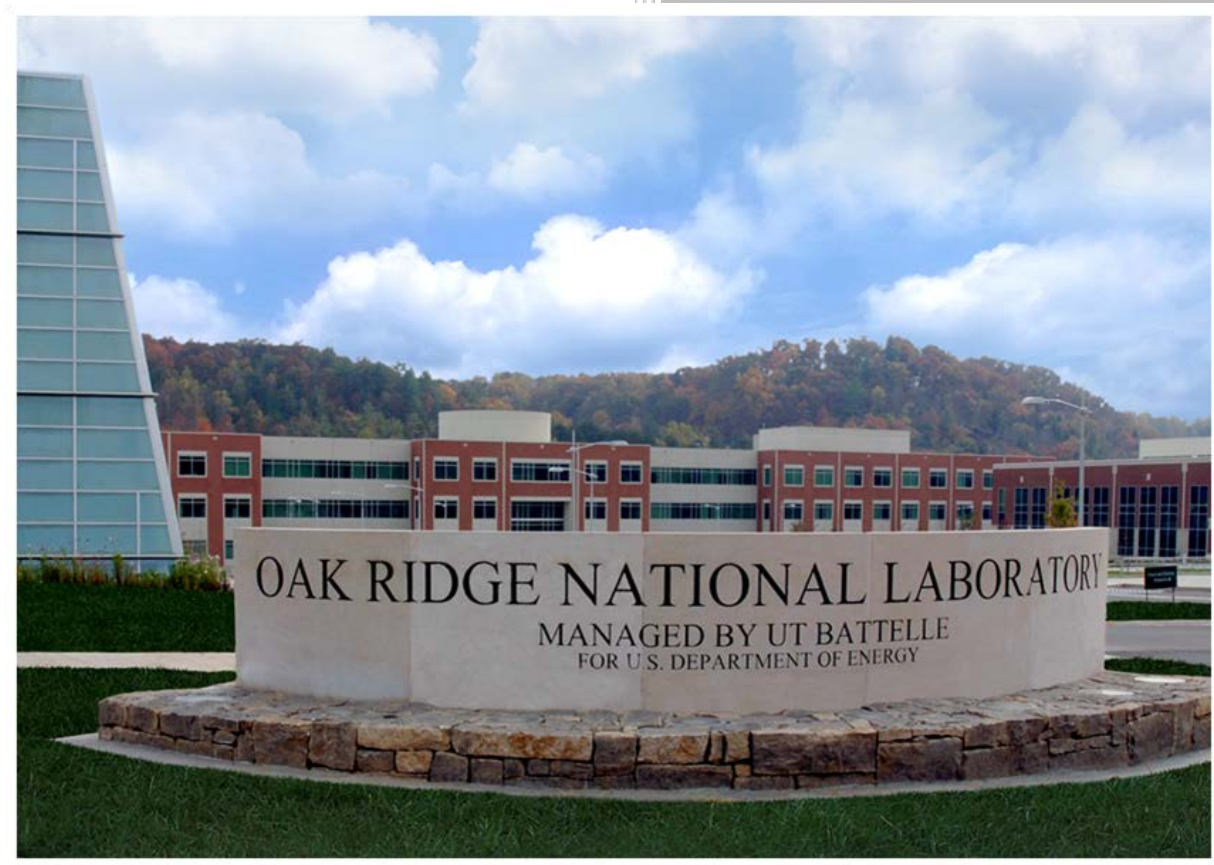

James Szybist

Scott Curran

April 2015 


\title{
DOCUMENT AVAILABILITY
}

Reports produced after January 1, 1996, are generally available free via US Department of Energy (DOE) SciTech Connect.

\section{Website http://www.osti.gov/scitech/}

Reports produced before January 1, 1996, may be purchased by members of the public from the following source:

\author{
National Technical Information Service \\ 5285 Port Royal Road \\ Springfield, VA 22161 \\ Telephone 703-605-6000 (1-800-553-6847) \\ TDD 703-487-4639 \\ Fax 703-605-6900 \\ E-mail info@ntis.gov \\ Website http://www.ntis.gov/help/ordermethods.aspx
}

Reports are available to DOE employees, DOE contractors, Energy Technology Data Exchange representatives, and International Nuclear Information System representatives from the following source:

Office of Scientific and Technical Information

PO Box 62

Oak Ridge, TN 37831

Telephone 865-576-8401

Fax 865-576-5728

E-mail reports@osti.gov

Website http://www.osti.gov/contact.html

This report was prepared as an account of work sponsored by an agency of the United States Government. Neither the United States Government nor any agency thereof, nor any of their employees, makes any warranty, express or implied, or assumes any legal liability or responsibility for the accuracy, completeness, or usefulness of any information, apparatus, product, or process disclosed, or represents that its use would not infringe privately owned rights. Reference herein to any specific commercial product, process, or service by trade name, trademark, manufacturer, or otherwise, does not necessarily constitute or imply its endorsement, recommendation, or favoring by the United States Government or any agency thereof. The views and opinions of authors expressed herein do not necessarily state or reflect those of the United States Government or any agency thereof. 
Energy \& Transportation Science Division

\title{
Corn Ethanol: The Surprisingly Effective Route for Natural Gas Consumption in the Transportation Sector
}

\author{
James Szybist and Scott Curran
}

Date Published: April 2015

Prepared by OAK RIDGE NATIONAL LABORATORY

Oak Ridge, TN 37831-6283

managed by

UT-BATTELLE, LLC

for the

US DEPARTMENT OF ENERGY

under contract DE-AC05-00OR22725 


\section{FOREWORD}

This analysis was submitted as an extended abstract for the 250th American Chemical Society (ACS) National Meeting and Exposition held in Boston, MA, August 16-20. The information is being re-

published here as an ORNL TM, but has otherwise not been changed with the exception of formatting. The extended abstract is being re-published to increase its accessibility and for ease-of-reference. 


\title{
Corn Ethanol: The Surprisingly Effective Route for Natural Gas Consumption in the Transportation Sector
}

\author{
James P. Szybist and Scott Curran \\ Fuels, Engines, and Emissions Research Center \\ Oak Ridge National Laboratory \\ szybistjp@ornl.gov
}

\section{Introduction}

Proven reserves and production of natural gas (NG) in the United States have increased dramatically in the last decade, due largely to the commercialization of hydraulic fracturing. This has led to a plentiful supply of NG, resulting in a significantly lower cost on a gallon of gasoline-equivalent (GGE) basis. Additionally, NG is a domestic, non-petroleum source of energy that is less carbon-intensive than coal or petroleum products, and thus can lead to lower greenhouse gas emissions.

Because of these factors, there is a desire to increase the use of NG in the transportation sector in the United States (U.S.). However, using NG directly in the transportation sector requires that several non-trivial challenges be overcome. One of these issues is the fueling infrastructure. There are currently only 1,375 ${ }^{1}$ NG fueling stations in the U.S. compared to $152,995{ }^{2}$ fueling stations for gasoline in 2014. Additionally, there are very few light-duty vehicles that can consume this fuel directly as dedicated or bi-fuel options. For example, in model year 2013Honda was the only OEM to offer a dedicated CNG sedan while a number of others offered CNG options as a preparation package for LD trucks and vans. In total, there were a total of 11 vehicle models in 2013 that could be purchased that could use natural gas directly. ${ }^{3}$

There are additional potential issues associated with NG vehicles as well. Compared to commercial refueling stations, the at-home refueling time for NG vehicles is substantial - a result of the small compressors used for home refilling. Additionally, the methane emissions from both refueling (leakage) and from tailpipe emissions (slip) from these vehicles can add to their GHG footprint, and while these emissions are not currently regulated it could be a barrier in the future, especially in scenarios with broad scale adoption of CNG vehicles.

However, NG consumption already plays a large role in other sectors of the economy, including some that are important to the transportation sector. Examples include steam reforming of natural gas to provide hydrogen for hydrotreating unit operations within the refinery and production of urea for use as a reductant for diesel after treatment in selective catalytic reduction (SCR). This discussion focuses on the consumption of natural gas in the production pathway of conventional ethanol (non-cellulosic) from corn through fermentation. Though it is clear that NG would also play a significant role in the cellulosic production pathways, those cases are not considered in this analysis. 


\section{NG Use in Ethanol Production Pathway}

It is widely known that there are a number of fossil energy inputs in the production of corn-based ethanol, including a number of early studies that concluded that ethanol production requires more energy input from fossil sources than is contained in the ethanol. ${ }^{4}$ The fossil energy input required to produce ethanol has been decreasing through advances in farming, ethanol processing, and distribution, and current analyses show that there is an average GHG reduction of 34\% from ethanol produced from corn. ${ }^{5}$ Currently, every liter of ethanol (21.3 MJ) requires 11.2 MJ of fossil energy input, or is $47.4 \%$ renewable on an energy content basis.

Thus, while $47.4 \%$ of the ethanol energy is renewable, corn-derived ethanol essentially acts as a carrier of fossil energy for the remaining 52.6\%. The fossil energy inputs required for ethanol production are well known and can be found in any of a number of life cycle analyses, and include transportation, farming, and irrigation. 5, 6, 7 The largest fossil energy input is the ethanol conversion and separation process, which is largely due to well-known energy intensity of the separation of ethanol from water. The second largest fossil energy input is the production of the nitrogen fertilizer. ${ }^{8}$ The fossil energy type for both ethanol conversion and drying and for the fertilizer production comes primarily from natural gas. ${ }^{5,6,7}$ While there are other energy inputs that can be used for ethanol production, such as coal, this analysis reflects that NG is the current fuel choice because it is the most economical choice.

The most up-to-date information on the energy inputs for corn ethanol is maintained in the GREET model, available through Argonne National Laboratory. ${ }^{9}$ A GREET analysis, Figure 1, shows the fraction of the energy in ethanol that is renewable, and the fraction that originates with natural gas on a GGE basis. This analysis shows that through a combination of fertilizer and ethanol conversion and drying, every GGE of ethanol requires 0.42 GGE of natural gas.

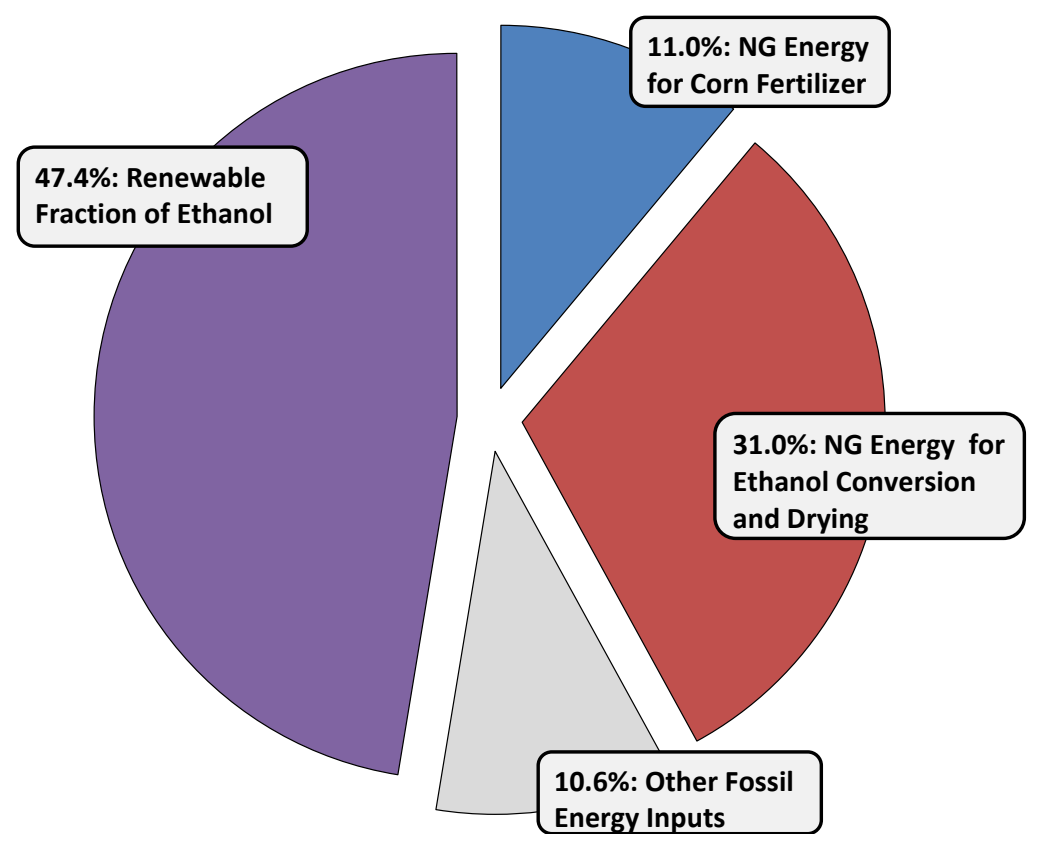

Figure 1. Ethanol energy input fractions. 
The enormous volume of ethanol production in the U.S. makes this contribution from NG significant on a national scale. In 2013, 13.31 billion gallons of ethanol were produced in the U.S., ${ }^{10}$ or 8.4 billion GGE. The amount of NG used to produce this volume of ethanol is 3.53 billion GGE, or 0.417 quadrillion BTU of NG.

The scale at which ethanol, and NG indirectly, is used in the transportation sector is a relatively recent phenomenon. The Energy Independence and Security Act of 2007 mandated that 36 billion gallons of renewable fuels be used annually by 2022. ${ }^{11}$ While ethanol is not the only renewable fuel that can be used to reach the mandate, it has been the primary fuel thus far. As a result of this law, ethanol production and consumption has increased dramatically, from less than 1.65 billion gallons per year in 2000 to 13.31 billion gallons in 2013.

This is a significant amount of displaced petroleum that would be challenging to equal with direct transportation use of NG. Assuming the 2012 values for vehicle efficiency and vehicle miles traveled, 12 consuming this amount of NG in the transportation sector would require 6.78 million light duty compressed natural gas (CNG) vehicles, or $6.1 \%$ of the total light duty vehicles on the road. Currently there are only 11 LD vehicle model offerings from OEMs to operate directly on natural gas, either as a dedicated CNG vehicle or as a bi-fuel model.

\section{Increasing the NG Contribution to the Transportation Sector}

Moving forward, the most effective way to increase the use of NG in the transportation sector is likely to increase the consumption of ethanol. Currently, most gasoline sold in the U.S. is E10, or a blend that contains $10 \%$ ethanol by volume with gasoline. E15, or a blend of $15 \%$ ethanol by volume with gasoline, was ruled by EPA to be a legal fuel for 2001 and newer vehicles. While this ruling continues to be a point of contention between EPA and OEMs for older vehicles, nearly 63\% of new vehicle models offered today are warranted by the manufacturer for E15 use ${ }^{13}$. If E15 is adopted nation-wide, the ethanol consumption, and corresponding NG consumption to produce the ethanol, will nominally increase $50 \%$, to 0.626 quadrillion BTU of NG. Beyond E15, further increases in ethanol use in the transportation sector are possible, with corresponding increases in NG in the production process.

Recent efforts have demonstrated potential efficiency advantages of even higher ethanol blends, from 2540 vol\% ethanol. $14,15,16$ With such blends it is possible to take advantage of the anti-knock properties of ethanol (high octane number and high latent heat of vaporization) but the volumetric energy density penalty remains within the range of where volumetric fuel economy parity is possible because of efficiency improvements. This is because the anti-knock properties of ethanol allow the compression ratio to be increased to achieve a higher thermal efficiency, and/or the power density of the engine can be increased to enable a higher vehicle system efficiency through downsizing and downspeeding the engine. Further, there are over 17 million flex fuel vehicles that are currently on the road that could use such a fuel immediately.

Increasing the ethanol concentration in gasoline has been a topic of discussion throughout industry for several years, as is evidenced by the High Octane Fuels Symposia. ${ }^{17,} 18$ While there would be a nontrivial infrastructure investment to increase the ethanol concentration in our gasoline to something in the 25-40\% range, it remains a possibility, and significantly more straightforward than development of NG infrastructure. 
Such an increase would also increase the indirect use of NG in the transportation sector by a proportionate amount, to nominally 1.04 quadrillion BTU for 25\% ethanol, to 1.67 quadrillion BTU for $40 \%$ ethanol. Figure 2 shows the number of light or heavy-duty vehicles that would be required to reach this same NG consumption directly. If only light-duty vehicles are used, $6 \%$ of all these vehicles would have to operate on NG to achieve the same NG consumption that E10 provides, and 24\% of all vehicles would be required to achieve the NG consumption with E40. Similarly, for class 7 and 8 combination trucks, $13 \%$ and $50 \%$ of these vehicles would be required to match the NG consumed through E10 and E40.

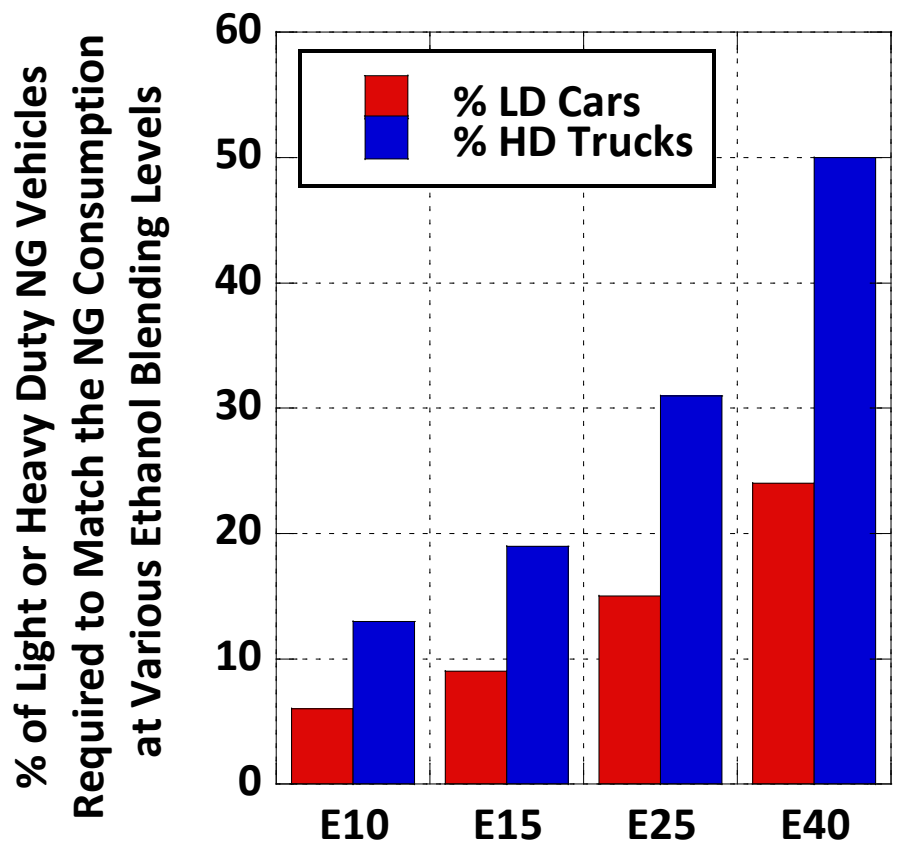

Figure 2. Percentage of light or heavy duty NG vehicle required to match the NG consumption at various ethanol blending level assumptions. Assumes constant 2012 fuel economy, vehicle registrations, and vehicle miles traveled. ${ }^{1,12}$

\section{Conclusions}

This analysis shows that ethanol is a surprisingly effective route for natural gas to displace petroleum energy use in the U.S. transportation sector.

- Takeaway\#1 - The U.S. currently uses a significant volume of NG through ethanol for transportation

- Takeaway\#2 - Increasing ethanol is perhaps the most effective way to increase NG consumption considering the infrastructure already in place in the U.S.

Acknowledgement. This report and the work described were sponsored by the U.S. Department of Energy (DOE) Office of Energy Efficiency and Renewable Energy (EERE) Vehicle Technologies Office. The authors gratefully acknowledge the support and direction of Kevin Stork at DOE. 


\section{References}

${ }^{1}$ Transportation Energy Data Book http://cta.ornl.gov/data/tedb33/Edition33_Chapter06.pdf

2 The Association of Convenience \& Fuel Retaling 2015 Report,

http://www.nacsonline.com/YourBusiness/FuelsReports/2015/RetailOperations/Pages/Who-Sells-AmericasFuel.aspx -

${ }^{3}$ US DOE Alternative Fuels Data Center http://www.afdc.energy.gov/data/10303

${ }^{4}$ Pimentel, D., “Ethanol Fuels: Energy Security, Economics, and the Environment.” Journal of Agriculture \& Environmental Ethics 4 (1991). DOI:10.1007/BF02229143.

${ }^{5}$ Wang, M., Han, J., Dunn, J.B., Cai, H., and Elgowainy, A., "Well-to-wheels energy use and greenhouse gas emissions of ethanol from corn, sugarcane, and cellulosic biomass for US use.” Environ. Res. Lett. 7 (2012). DOI:10.1088/1748-9326/7/4/045905.

${ }^{6}$ Shapouri, H., Duffield, J.A., Wang, M., “The Energy Balance of Corn Ethanol: An Update.” USDA Agricultural Economic Report Number 814 (2002).

http://ageconsearch.umn.edu/bitstream/34075/1/ae020814.pdf

${ }^{7}$ Shapouri, H., Gallagher, P.W., Nefstead, W., Schwartz, R., Noe, S., and Conway, R., “2008 Energy Balance for the Corn-Ethanol Industry,” USDA Agricultural Economic Report Number 846 (2010). http://www.usda.gov/oce/reports/energy/2008Ethanol_June_final.pdf

${ }^{8}$ Johnson, M.C., Palou-Rivera, I., and Frank, E.D., "Energy Consumption During the Manufacture of Nutrients for Algae Cultivation,” Algal Research 2 (2013), DOI: 10.101/j.algal.2013.08.003.

${ }^{9}$ GREET model available through Argonne National Laboratory, https://greet.es.anl.gov/greet/index.htm, accessed April 6, 2015.

${ }^{10}$ Energy Information Agency by the U.S. Department of Energy. http://www.eia.gov/tools/faqs/faq.cfm?id=90\&t=4, accessed April 6, 2015.

${ }^{11}$ One Hundred Tenth Congress of the United States of America, Energy Independence and Security Act of 2007. 2007; H.R. 6.

12 Transportation Energy Data Book http://cta.ornl.gov/data/tedb33/Edition33_Chapter04.pdf

${ }^{13}$ RFA News, 2014, http://www.ethanolrfa.org/news/entry/automakers-approve-e15-for-use-in-two-thirdsof-new-vehicles/

${ }^{14}$ T., Olin, E., Anderson, J., Jung, H. et al., "Effects of Fuel Octane Rating and Ethanol Content on Knock, Fuel Economy, and CO2 for a Turbocharged DI Engine," SAE Int. J. Fuels Lubr. 7(1):9-28, 2014, doi:10.4271/2014-01-1228.

${ }^{15}$ Splitter, D.A., and Szybist, J.P., "Experimental Investigation of Spark-Ignited Combustion with HighOctane Biofuels and EGR. 1. Engine Load Range and Downsize Downspeed Opportunity,” Energy \& Fuels, 28(2): 1418-1431, 2014, doi:10.1021/ef0401574p.

${ }^{16}$ Splitter, D.A., and Szybist, J.P., "Experimental Investigation of Spark-Ignited Combustion with HighOctane Biofuels and EGR. 2. Fuel and EGR Effects on Knock-Limited Load and Speed,” Energy \& Fuels, 28(2): 1432-1445, 2014, doi:10.1021/ef401575e.

172013 SAE International High Octane Fuels Symposium: the potential for high octane fuels (Part 1), Green Car Congress 2013, http://www.greencarcongress.com/2013/01/hofs-20130131.html

${ }^{18}$ SAE High Octane Fuels Symposium: (part 2), Green Car Congress, 2013, http://www.greencarcongress.com/2013/02/saehofs-20130206.html 